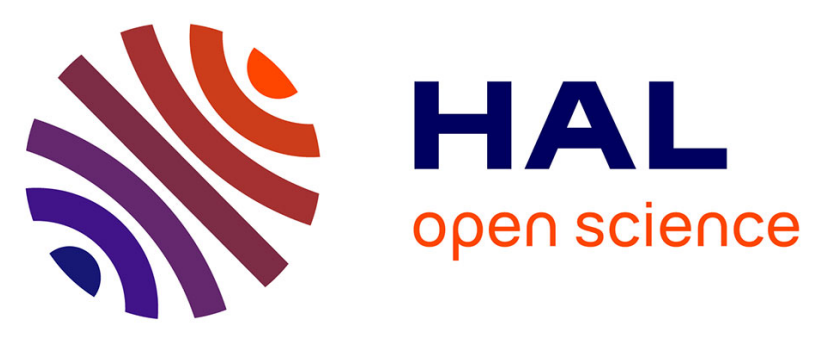

\title{
Nanohybrids with Magnetic and Persistent Luminescence Properties for Cell Labeling, Tracking, In Vivo Real-Time Imaging, and Magnetic Vectorization
} Eliott Teston, Thomas Maldiney, Iris Marangon, Jeanne Volatron, Yoann Lalatonne, Laurence Motte, Catherine Boisson-Vidal, Gwennhael Autret, Olivier Clément, Daniel Scherman, et al.

\section{To cite this version:}

Eliott Teston, Thomas Maldiney, Iris Marangon, Jeanne Volatron, Yoann Lalatonne, et al.. Nanohybrids with Magnetic and Persistent Luminescence Properties for Cell Labeling, Tracking, In Vivo Real-Time Imaging, and Magnetic Vectorization. Small, 2018, 14 (16), pp.1800020. 10.1002/smll.201800020 . hal-02327091

\section{HAL Id: hal-02327091 \\ https://hal.science/hal-02327091}

Submitted on 25 Oct 2019

HAL is a multi-disciplinary open access archive for the deposit and dissemination of scientific research documents, whether they are published or not. The documents may come from teaching and research institutions in France or abroad, or from public or private research centers.
L'archive ouverte pluridisciplinaire HAL, est destinée au dépôt et à la diffusion de documents scientifiques de niveau recherche, publiés ou non, émanant des établissements d'enseignement et de recherche français ou étrangers, des laboratoires publics ou privés. 


\title{
Nanohybrids with Magnetic and Persistent Luminescence Properties for Cell Labeling, Tracking, In Vivo Real-Time Imaging, and Magnetic Vectorization
}

\author{
Eliott Teston, Thomas Maldiney, Iris Marangon, Jeanne Volatron, Yoann Lalatonne, \\ Laurence Motte, Catherine Boisson-Vidal, Gwennhael Autret, Olivier Clément, \\ Daniel Scherman, Florence Gazeau, and Cyrille Richard**
}

Once injected into a living organism, cells diffuse or migrate around the initial injection point and become impossible to be visualized and tracked in vivo. The present work concerns the development of a new technique for therapeutic cell labeling and subsequent in vivo visualization and magnetic retention. It is hypothesized and subsequently demonstrated that nanohybrids made of persistent luminescence nanoparticles and ultrasmall superparamagnetic iron oxide nanoparticles incorporated into a silica matrix can be used as an effective nanoplatform to label therapeutic cells in a nontoxic way in order to dynamically track them in real-time in vitro and in living mice. As a proof-of-concept, it is shown that once injected, these labeled cells can be visualized and attracted in vivo using a magnet. This first step suggests that these nanohybrids represent efficient multifunctional nanoprobes for further imaging guided cell therapies development.

\section{Introduction}

In recent years, cells have shown great potential in a number of biomedical applications and researches in this area received much attention. ${ }^{[1]}$ Cell therapies using mesenchymal stem cells (MSC) or endothelial progenitor cells (EPC) have demonstrated significant potential for the treatment and cure of several diseases such as cancer, diabetes, neurodegenerative or cardiovascular diseases ${ }^{[2-4]}$ and also for regeneration in peripheral arterial disease in both animal and human studies..$^{[5,6]}$

Most current preclinical and clinical cell therapy trials consist of local or systemic delivery of stem or progenitor cells, and rely on the migration and retention of implanted cells at sites of injury. ${ }^{[7]}$ However, determining the fate and localization of these cells inside the body, as well as targeting the cells to a particular location, are still major challenges. To address these concerns, several methods have been developed to label therapeutic cells ex vivo in order to monitor their fate after in vivo administration. Among the different available modalities, X-ray computed tomography $(\mathrm{CT}),{ }^{[8]}$ magnetic resonance imaging (MRI), ${ }^{[9]}$ positron emission tomography, ${ }^{[10]}$ and single photon emission computed tomography[11] have been used. However, the detection sensitivity of transplanted cells using such techniques is in some cases very low, or rendered difficult and costly by the use of radiopharmaceutical compounds. Optical imaging is expected to contribute to the development of cell transplantation, as it is less costly, easier to handle, nonionizing, and very sensitive. ${ }^{[12]}$ For that purpose, various optical labeling techniques have been developed to
Dr. E. Teston, Dr. T. Maldiney, Prof. D. Scherman, Dr. C. Richard

Unité des Technologies Chimiques et Biologiques

pour la Santé (UTCBS)

UMR 8258 CNRS

U 1022 Inserm

Faculté de Pharmacie de Paris

Université Paris Descartes

Sorbonne Paris Cité

F-75270 cedex France, Chimie Paristech, Paris F-75231 cedex, France

E-mail: cyrille.richard@parisdescartes.fr

Dr. I. Maragon, J. Volatron, Dr. F. Gazeau

Laboratoire Matière et Systèmes Complexes (MSC)

UMR 7057 CNRS

Université Paris Diderot

Paris 75205 cedex, France

DOI: $10.1002 / \mathrm{smll} .201800020$

\author{
Dr. Y. Lalatonne, Prof. L. Motte \\ Laboratoire de Chimie, Structures \\ Propriétés de Biomatériaux et d'Agents Thérapeutiques (CSPBAT) \\ UMR 7244 CNRS \\ Université Paris \\ Bobigny 93017, France \\ Dr C. Boisson-Vidal \\ Unité mixte de recherche 1140 - Thérapeutiques innovantes en hémostase \\ Faculté de Pharmacie de Paris \\ F-75270 cedex, France \\ Dr. G. Autret, Prof. O. Clément \\ Laboratoire de Recherche en Imagerie, EA 4062 \\ Inserm U 970 ou 494 \\ Equipe 2, PARCC \\ Université Paris Descartes \\ Hôpital Européen George Pompidou \\ Paris 75015, France
}



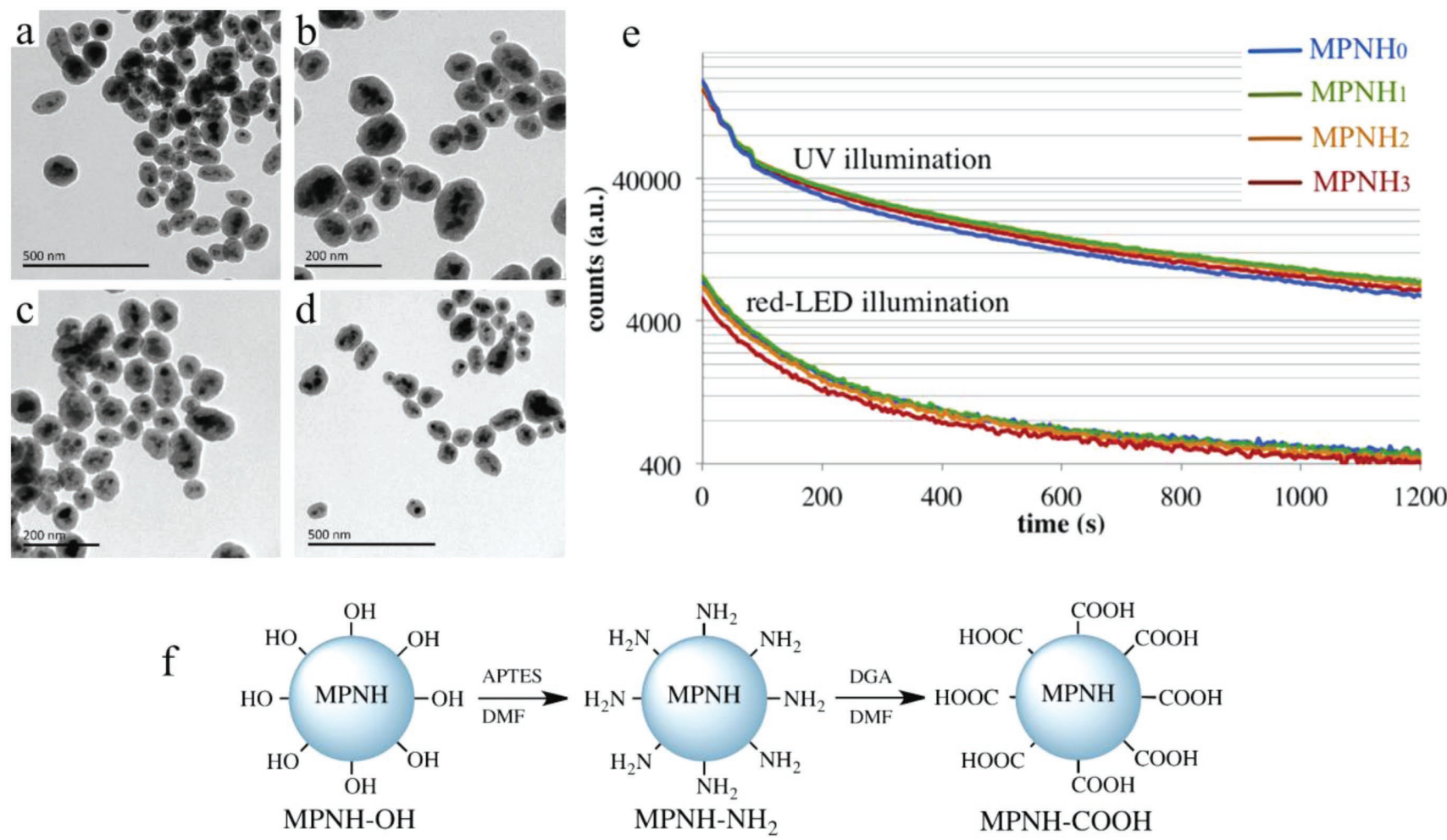

Figure 1. TEM images of nonfunctionalized a) $\mathrm{MPNH}_{0}$, b) $\mathrm{MPNH}_{1}$, c) $\mathrm{MPNH}_{2}$, and d) $\mathrm{MPNH}_{3}$. e) Decay curves of MPNHs after 2 min UV (254 nm) or red-LED illumination. Persistent luminescence intensity is expressed in log10 scale in arbitrary units. f) Synthetic pathway from MPNHs-OH to MPNHs-COOH. Adapted with permission. ${ }^{[31]}$ Copyright 2007, American Society of Hematology.

apprehend cell behavior in vitro and in vivo. ${ }^{[13]}$ However, optical in vivo detection is impaired by the autofluorescence signal coming from the body when exciting the probes. ${ }^{[14]}$ To overcome this parasitic signal, our group pioneered the use of persistent luminescent nanoparticles (PLNPs) for in vivo imaging. Acting as optical capacitors, PLNPs can emit light in the tissue transparency window for minutes to hours after the end of an UV or visible illumination, leading to signals without autofluorescence and high target to background ratio. ${ }^{[15-20]}$ Recently, ultrasensitive detection of labeled cells in small animals either after intravenous or subcutaneous injection was demonstrated in preliminary studies using PLNPs. ${ }^{[18,21,22]}$

The long-term efficacy of stem cells therapy is presently relatively low, which can be due to a lack of cell retention in the treatment area, ${ }^{[23]}$ misplaced-injection, or cell injection into highly fibrotic tissues. ${ }^{[2]}$ Fortunately, unproperly localized injection can be prevented by real-time imaging guidance to ensure sufficient cell delivery to the desired tissue location. In order to improve cell delivery, several reports have shown that the in vivo biodistribution of cells labeled with magnetic nanoparticles could be influenced by applying a magnetic field and gradient. ${ }^{[25,26]}$ Various preclinical studies have exploited the magnetic properties acquired by cells carrying magnetic nanoparticles in order to increase the retention of implanted cells at specific sites within the body, for example with endothelial cells or EPC. ${ }^{[27-29]}$

Recently, we have developed a modified approach to synthesize a new class of mesoporous nanohybrids (MPNHs) consisting of PLNPs and USPIOs incorporated into the same mesoporous silica matrix. ${ }^{[30]}$ We thus wondered whether these new nanohybrids could be used to label cells of interest in order to both control their in vivo fate, using their magnetic property, and to follow in real time their distribution, using their persistent luminescent property, after injection. As a model, we chose a subpopulation of EPC called "late" EPC or endothelial colony-forming cells (ECFC) that present blood vessel-forming ability. ${ }^{[31,32]}$ Herein, we report the use of MPNHs to label ECFC in nontoxic conditions, allowing these cells to keep their proliferation ability and biological properties. After labeling, it was possible to detect the cells in vivo and we show that MPNHs-COOH labeled ECFC can be remotely controlled in vivo by applying an external magnetic field and gradient.

\section{Results and Discussion}

\subsection{Characterization and Functionalization of the Nanohybrids}

We have previously reported the synthesis of different MPNH made of PLNPs and containing increasing amount of USPIOs $\left(0,1.4,3.5\right.$, and $5.2 \%(\mathrm{w} / \mathrm{w})$, named $\mathrm{MPNH}_{0}$, $\mathrm{MPNH}_{1}, \mathrm{MPNH}_{2}$, and $\mathrm{MPNH}_{3}$, respectively) incorporated into a silica matrix (Figure 1a-d). These nanohybrids have been synthesized using tetraethoxysilane (TEOS), cetyltrimethylammonium bromide (CTAB), and comprise the two types of nanoparticles (PLNPs and USPIOs). ${ }^{[30]}$ In order to evaluate the influence of the nanohybrids surface both 
on the internalization efficacy and on the cell cytotoxicity, these nanohybrids have been coated either with (3-aminopropyl)triethoxysilane (APTES) to introduce amine groups on the MPNHs $\left(\mathrm{MPNH}-\mathrm{NH}_{2}\right)$ or with diglycolic anhydride (DGA) to introduce carboxylic acids functions (MPNH$\mathrm{COOH}$ ) (Figure 1f). The different MPNHs have a spherical-like shape (Figure 1a-d) and persistent luminescence properties after both UV and visible excitation (Figure 1e). The light emission can persist for several dozen of minutes after the end of the excitation, which is necessary to get in vivo optical signals without background. Figure 1e also informs about the compared efficacy of UV versus visible illumination. As shown on the corresponding decay curves, the persistent luminescence signal is approximately one log weaker following visible light excitation, in comparison with the signal obtained following UV excitation. Such typical trend regarding the persistent luminescence signal of these MPNHs matches the results demonstrated earlier in several other studies from our group. ${ }^{[30,33]}$ More importantly, the persistent luminescence properties of MPNHs do not vary with the percentage of USPIO (Figure 1e). As expected, the functionalization procedure has an effect on the zeta potential of the MPNHs: MPNHs- $\mathrm{NH}_{2}$, with the amino groups, are protonated in $\mathrm{mQ}$ water and have positive surface charges, whereas MPNHs-COOH, with the carboxylic acids, have negative zeta potentials (Table 1). In addition, the amount of USPIOs does not seem to have any major impact on the global physicochemical properties of the MPNHs. Notably, all MPNHs display both similar zeta potential, either positive around $+40 \mathrm{mV}$ with MPNHs- $\mathrm{NH}_{2}$ or negative around $-40 \mathrm{mV}$ with MPNHs$\mathrm{COOH}$, and hydrodynamic diameters which are rather stable around $190 \mathrm{~nm}$ from $\mathrm{MPNH}_{0}-\mathrm{COOH}$ to $\mathrm{MPNH}_{3}-\mathrm{COOH}$.

\subsection{In Vitro Cell Labeling and Toxicity Assays}

As a cell model we have chosen ECFC, a variety of endothelial progenitors. ${ }^{[31,32]}$ Thus, our objective was to find nontoxic conditions to label ECFC with MPNH and allow in vivo cell tracking under magnetic control.

We first assessed the influence of three parameters designated as the type of MPNH, the surface coating $\left(-\mathrm{NH}_{2}\right.$ or $\left.-\mathrm{COOH}\right)$ and the incubation time (6 and $24 \mathrm{~h}$ ) on the global ECFCs viability. To this end, 10000 cells deposited in 96-well plates were incubated with increasing amounts of nanoparticles. The Alamar blue test was used to evaluate the cell metabolic activity. As can be observed in Figure 2, the coating has an influence on cell viability. When we look at $\mathrm{MPNH}_{0}$ (nanohybrids with $0 \%$ of USPIOs), we can verify that amine-coated MPNHs are more cytotoxic than the carboxylic coated ones (Figure 2a). This is certainly due to the positive charge of amine-coated MPNHs, leading to a higher cellular uptake as can be seen in the literature. ${ }^{[34,35]}$ This apparent toxicity is even more important when the incubation time increases from 6 to $24 \mathrm{~h}$. In contrast to particle coating, the amount of USPIOs in MPNH type $\left(\mathrm{MPNH}_{1-3}\right)$ has little influence on the cell viability (Figure 2a-d). Such absence of effect could be attributed to the fact that USPIOs are incorporated into the core of the silica matrix, therefore not in direct contact with the cells. Moreover, this trend is also in
Table 1. DLS measurements giving hydrodynamic diameters and $\zeta$-potentials of MPNHs- $\mathrm{NH}_{2}$ and MPNHs- $\mathrm{COOH}$.

\begin{tabular}{lcccc}
\hline & $\begin{array}{c}\text { Potential } \zeta \\
{[\mathrm{mV}]}\end{array}$ & & $\begin{array}{c}\text { Hydrodynamic } \\
\text { diameter [nm]/ } \\
\text { polydispersity } \\
\text { index }\end{array}$ & $\begin{array}{c}\text { Potential } \zeta \\
{[\mathrm{mV}]}\end{array}$ \\
\hline $\mathrm{MPNH}_{0}-\mathrm{NH}_{2}$ & $36.2 \pm 1,9$ & $\mathrm{MPNH}_{0}-\mathrm{COOH}$ & $200 / 0.024$ & $-44.7 \pm 2.1$ \\
$\mathrm{MPNH}_{1}-\mathrm{NH}_{2}$ & $38.3 \pm 0,9$ & $\mathrm{MPNH}_{1}-\mathrm{COOH}$ & $185 / 0.046$ & $-42.2 \pm 2.1$ \\
$\mathrm{MPNH}_{2}-\mathrm{NH}_{2}$ & $46.3 \pm 2,4$ & $\mathrm{MPNH}_{2}-\mathrm{COOH}$ & $191 / 0.050$ & $-39.2 \pm 2.2$ \\
$\mathrm{MPNH}_{3}-\mathrm{NH}_{2}$ & $35.7 \pm 2,7$ & $\mathrm{MPNH}_{3}-\mathrm{COOH}$ & $186 / 0.052$ & $-40.0 \pm 2.6$ \\
\hline
\end{tabular}

line with previous work in which USPIOs alone are not responsible for any significant cytotoxic effect at these concentrations $\left(<1 \times 10^{-3} \mathrm{M}\right)$ on endothelial cells. ${ }^{[36,37]}$ Finally, we observed that the low cytotoxicity of MPNHs-COOH is time independent.

Beside the assessment of cellular metabolic activity by Alamar blue test, a cell proliferation assay was carried out up to 7 days postlabeling. For this purpose, we selected a concentration of MPNHs for which the cell viability with the Alamar blue test was above $80 \%$ at 24 h, i.e., $0.25 \mathrm{mg} \mathrm{mL}^{-1}$ (which correspond to $73.5 \mu \mathrm{g}$ of $\mathrm{MPNH}$ per $\mathrm{cm}^{2}$ ). As can be seen from Figure 2e, exposure of ECFC to $\mathrm{MPNH}_{3}-\mathrm{NH}_{2}$ appears to significantly alter the proliferation, as compared to a control group (CT). These results are consistent with our previous observation using the Alamar blue test. On the other hand, incubation of ECFC with $\mathrm{MPNH}_{3}-\mathrm{COOH}$ does not alter the proliferation of ECFC even after 7 days of proliferation (Figure 2e).

\subsection{Cellular Uptake of Nanohybrids and Optomagnetic Properties of Labeled Cells}

To determine the cell uptake of the MPNHs, different techniques have been used. Since the MPNHs-COOH are less cytotoxic, a concentration of $73.5 \mu \mathrm{g} \mathrm{cm}^{-2}\left(0.25 \mathrm{mg} \mathrm{mL}^{-1}\right)$ for each MPNH-COOH was chosen for subsequent experiments. Transmission electron microscopy (TEM) observations of ECFC (6 $\mathrm{h}$ after labeling) principally show intraendosomal confinement of the different $\mathrm{MPNH}_{1-3}-\mathrm{COOH}$ (Figure $3 \mathrm{a}-\mathrm{c}$ ), thus indicating that the low toxicity obtained by Alamar blue and proliferation tests are not the consequence of an absence of MPNHs-COOH internalization. We can also observe that these nanoparticles are internalized in different ways: some MPNHs are observed in small intracellular vesicles, while the majority are clustered in large lysosome-like vesicles. MPNHs isolated in small vesicles probably follow clathrin-dependent endocytosis, as previously shown with silica nanoparticles of about one hundred nanometers. ${ }^{[38]}$

In order to quantify the amount of MPNHs internalized by the cells, a magnetophoresis experiment was performed with cells labeled under conditions identical to that of the TEM experiment. By exploiting the magnetophoretic mobility of each labeled cell in suspension in a magnetic field gradient, we were able to determine the mass of iron per cell, deduced from the measurements of single cell velocity toward the magnet and cell radius (Figure 3d). ${ }^{[39]}$ Depending on the initial amount of USPIOs in MPNHs, the average mass 

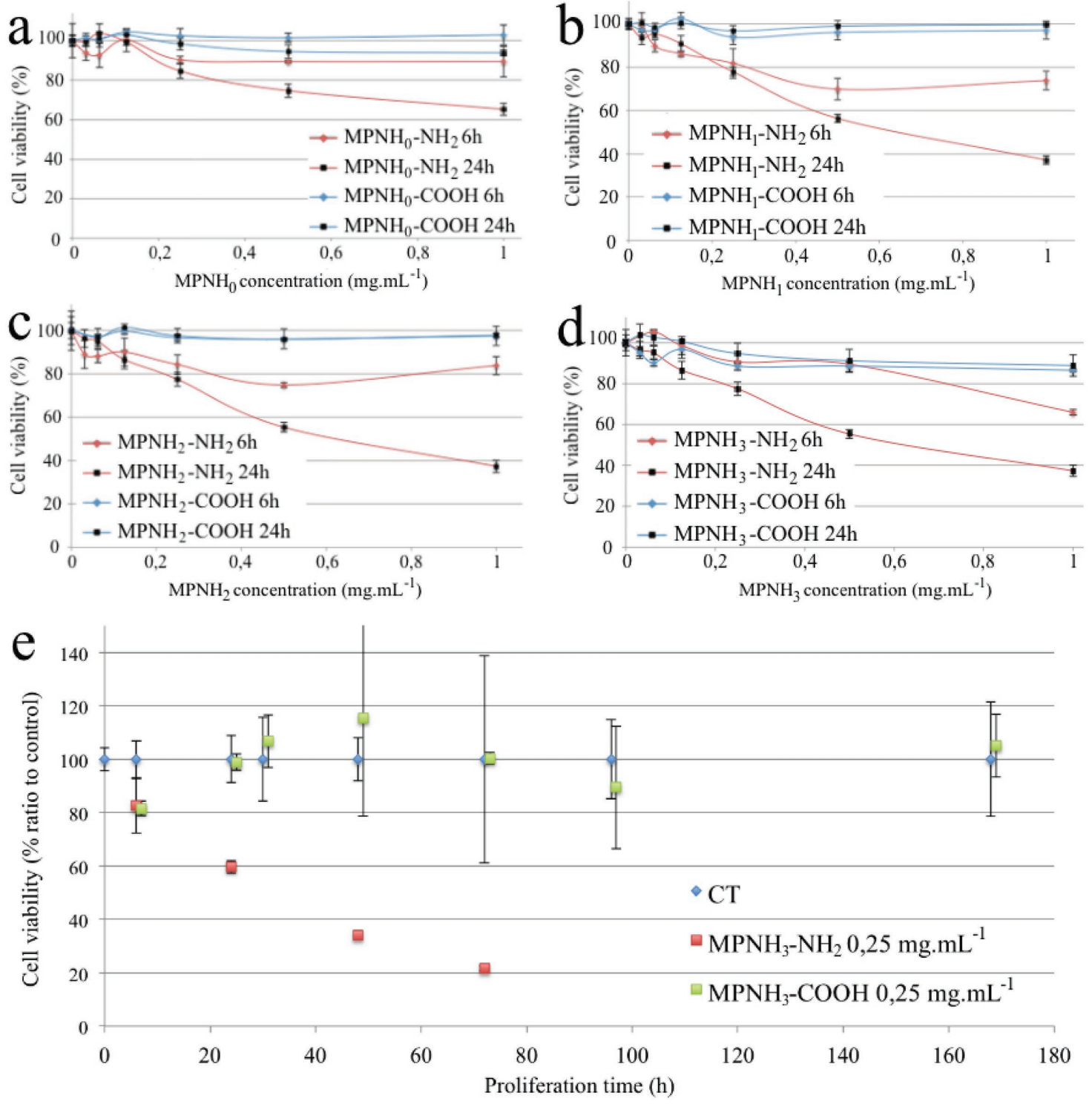

Figure 2. Cytotoxicity of MPNHs in ECFC. a-d) Percentage of viability after 6 (red and blue diamonds) or $24 \mathrm{~h}$ (black squares) of incubation with MPNHs-NH (red curves) or MPNHs-COOH (blue curves). All types of MPNH (MPNH $\mathrm{MPNH}_{3}$, as shown on graphs (a) to (d), respectively) were tested for concentrations from $31.25 \mu \mathrm{g} \mathrm{mL}^{-1}\left(9.19 \mu \mathrm{g} \mathrm{cm}^{-2}\right)$ to $1 \mathrm{mg} \mathrm{mL}^{-1}\left(294 \mu \mathrm{g} \mathrm{cm}^{-2}\right)$. e) Cell proliferation after incubation in the absence (control, blue diamonds) or presence of $\mathrm{MPNH}_{3}-\mathrm{NH}_{2}$ (red squares) or $-\mathrm{COOH}$ (green squares) (incubation time $6 \mathrm{~h}$, concentration of $0.25 \mathrm{mg} \mathrm{mL}^{-1} / 73.5 \mu \mathrm{g} \mathrm{cm}{ }^{-2}$ ). Proliferation capacity was not affected by the carboxylic coating, as opposed to the amino coating, compared with growth capacity in control.

of iron per cell approximately varies from 1.7 to $3 \mathrm{pg}$. These results are consistent with previous studies reporting EPC labeling with similar USPIOs, which obtained iron load from $3^{[27]}$ to $10^{[36]}$ pg per cell after incubation with iron concentrations of 0.1 or $5 \times 10^{-3} \mathrm{M}$. In our case, we used lower iron concentrations ranging from 0.043 to $0.16 \times 10^{-3} \mathrm{M}$ (for $0.25 \mathrm{mg} \mathrm{mL}-1$ of $\mathrm{MPNH}_{1}$ and $\mathrm{MPNH}_{3}$, respectively) and USPIO were embedded in the silica matrix. In addition to the mean cellular magnetic load, this assay allows determining the iron mass distribution in the cell population (Figure S1, Supporting Information). As MPNHs compositions were previously determined using ICP-MS, ${ }^{[30]}$ we could determine the average mass of MPNHs per cell from the magnetophoresis data (Figure 3e). Unexpectedly, the data from Figure $3 \mathrm{e}$ indicate that the final amount of MPNHs per cell depends on the type of MPNHs. Indeed, the higher the USPIOs load in MPNHs, the lower the MPNHs uptake within each cell. Cells labeled with $\mathrm{MPNH}_{2}-\mathrm{COOH}$ contain the same amount of iron as those labeled with $\mathrm{MPNH}_{3}-\mathrm{COOH}$ (Figure 3d). Thus, $\mathrm{MPNH}_{3}$ are less internalized than $\mathrm{MPNH}_{2}$ and $\mathrm{MPNH}_{1}$.

After the magnetophoresis experiments, the cells were embedded in an agarose gel $\left(1.5 .10^{6}\right.$ cells per $\left.\mathrm{mL}\right)$ to be characterized by MRI spectrometry in order to measure both T1 and T2 relaxation times (Figure 3f; Figure S2, Supporting Information). The presence of USPIOs in cells shows a slight but nonsignificant influence on T1-weighted images, and no difference between the T1 of the gel containing the nonmagnetic $\mathrm{MPNH}_{0^{-}}$ $\mathrm{COOH}$ labeled ECFC when compared to the control (Figure S2, 

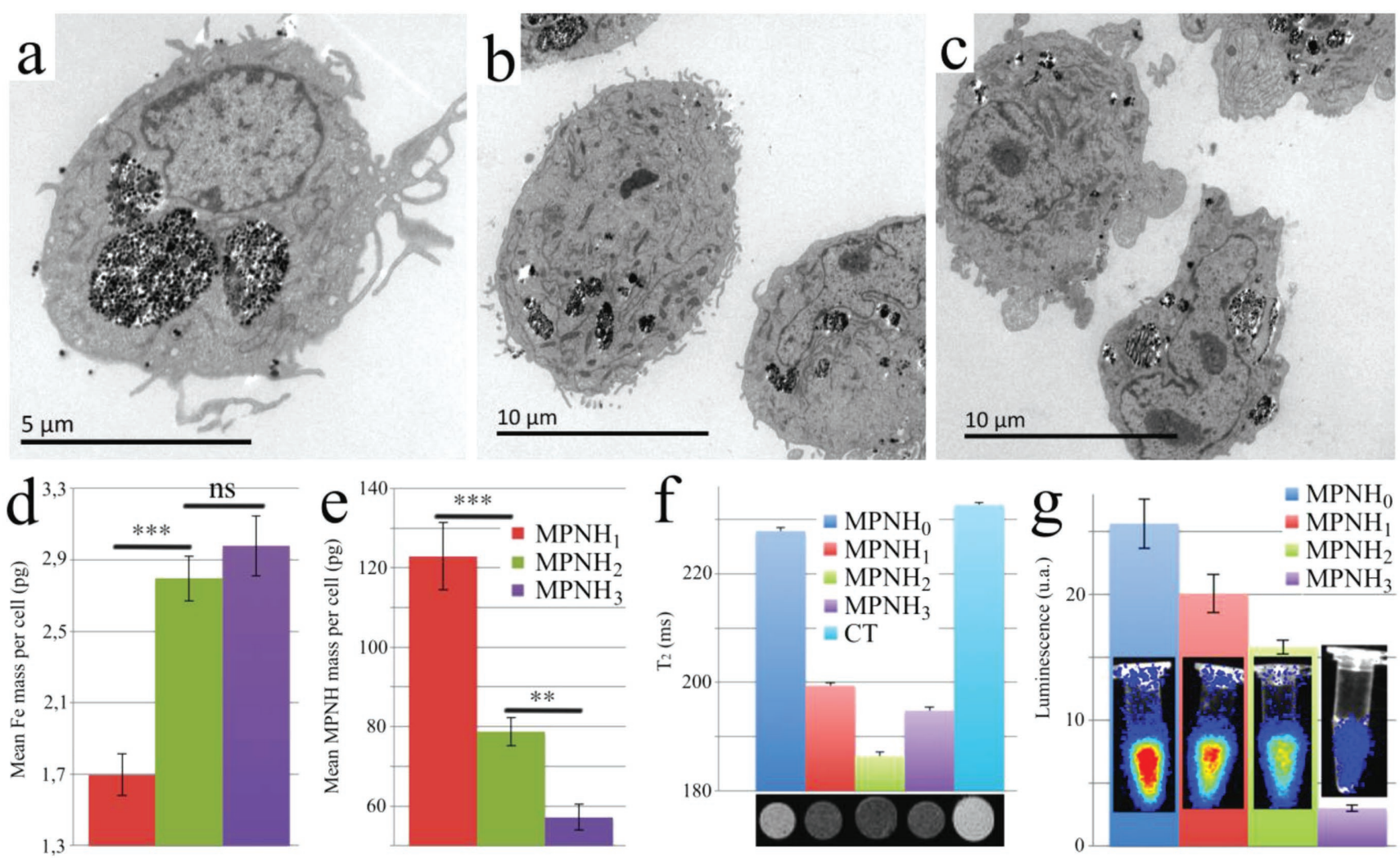

Figure 3. Optical and magnetic characterizations of MPNHs labeled ECFC. a-c) Electron microcope images of ECFC after $6 \mathrm{~h}$ of incubation with a) $\mathrm{MPNH}_{1}-\mathrm{COOH}$, b) $\mathrm{MPNH}_{2}-\mathrm{COOH}$, and c) $\mathrm{MPNH}_{3}-\mathrm{COOH}\left(0.25 \mathrm{mg} \mathrm{mL}^{-1} / 73.5 \mu \mathrm{g} \mathrm{cm}^{-2}\right)$. d) Fe and e) $\mathrm{MPNH}_{1,2,3}-\mathrm{COOH}$ mean load per cell after incubation. Statistical analyses were realized using an Anova test followed by a Bonferroni comparison. Bar graphs show mean $\pm \mathrm{SEM}(n=88,178$, and 109 for $\mathrm{MPNH}_{1}, \mathrm{MPNH}_{2}$, and $\mathrm{MPNH}_{3}$, respectively). $*$ and $\mathrm{w}^{\prime} *$ correspond to $p<0.01$ and 0.001 , respectively. f) T2 MRI measurements and images of agarose gels with 1.5.106 ECFC mL $\mathrm{mL}^{-1}$. Control tube (CT, sky blue) contains the same concentration of unlabeled ECFC. Bar graph shows mean \pm SD, images of corresponding tubes are shown under the graphics. g) Persistent luminescence of previously described agarose gels after 5 min of red-LED illumination (bar graph shows mean $\pm \mathrm{SD}$ ).

Supporting Information). As expected from magnetically labeled cells, the contrast evolution is much more important when looking at T2-weighted images. ${ }^{[40]}$ The gel containing the nonmagnetic $\mathrm{MPNH}_{0}-\mathrm{COOH}$ labeled cells (dark blue column) displayed a contrast similar to the control gel containing unlabeled ECFC (light blue column), but the gels containing cells labeled with magnetic $\mathrm{MPNH}_{1,2,3}$ have a much lower T2 than the control (Figure 3f).

Due to the dual imaging properties of PLNPs, the labeled cells can be readily detected through their luminescence emission. We compared the luminescence intensity of cells labeled with the four MPNHs under the same conditions. The gels previously used for the MRI experiment were illuminated with a visible light emitting diode (LED) and the persistent luminescence was measured (Figure $3 \mathrm{~g}$ ). After visible illumination, the luminescence of the labeled cells clearly depends on the type of MPNH used. The more USPIO concentration in MPNHs, the lower is the cell luminescence. These variations in the luminescence emission are well correlated to the different cellular uptake reported before (Figure 3e). While $\mathrm{MPNH}_{3}-\mathrm{COOH}$ labeled cell has similar iron content and magnetophoretic mobility compared to $\mathrm{MPNH}_{2}$-COOH labeled cell, their luminescence is six times lower than those labeled with $\mathrm{MPNH}_{2}-\mathrm{COOH}$ (Figure 3g) which is in line with the different cell uptake. In addition, despite the higher luminescence intensity of $\mathrm{MPNH}_{1}-\mathrm{COOH}$ labeled cells, their magnetic resonance detectability and magnetic attraction are very low compared to $\mathrm{MPNH}_{2}-\mathrm{COOH}$ labeled cells. Therefore, in a trade-off between cellular uptake, luminescence detection, MR detection, and magnetophoretic mobility of cells, $\mathrm{MPNH}_{2}-\mathrm{COOH}$ appears as the best candidate to carry out further in vivo dual image-guided and magnetically targeted cellular vectorization experiment.

\subsection{Functional Properties of Labeled Cells}

For in vivo cell-based therapy, labeled progenitor cells should maintain crucial biological properties such as migration and capillary network formation abilities. ${ }^{[37,41-43]}$ Thus, we performed two sets of experiments to evaluate these properties. In vitro, the study of cell migration was carried out using a wound healing assay. ${ }^{[44]}$ We created a wound gap in a MPNH-labeled ECFC monolayer by scratching and monitored their migration toward the gap. The remaining gaps in MPNH-treated wells were measured when control scratches had disappeared, around $24 \mathrm{~h}$ after their realization. Thus, injured areas were photographed to assess healing in each area. Figure 4a shows the initial injuries $\left(t_{0}\right)$ and $24 \mathrm{~h}$ later $(24 \mathrm{~h})$. The wounds are 


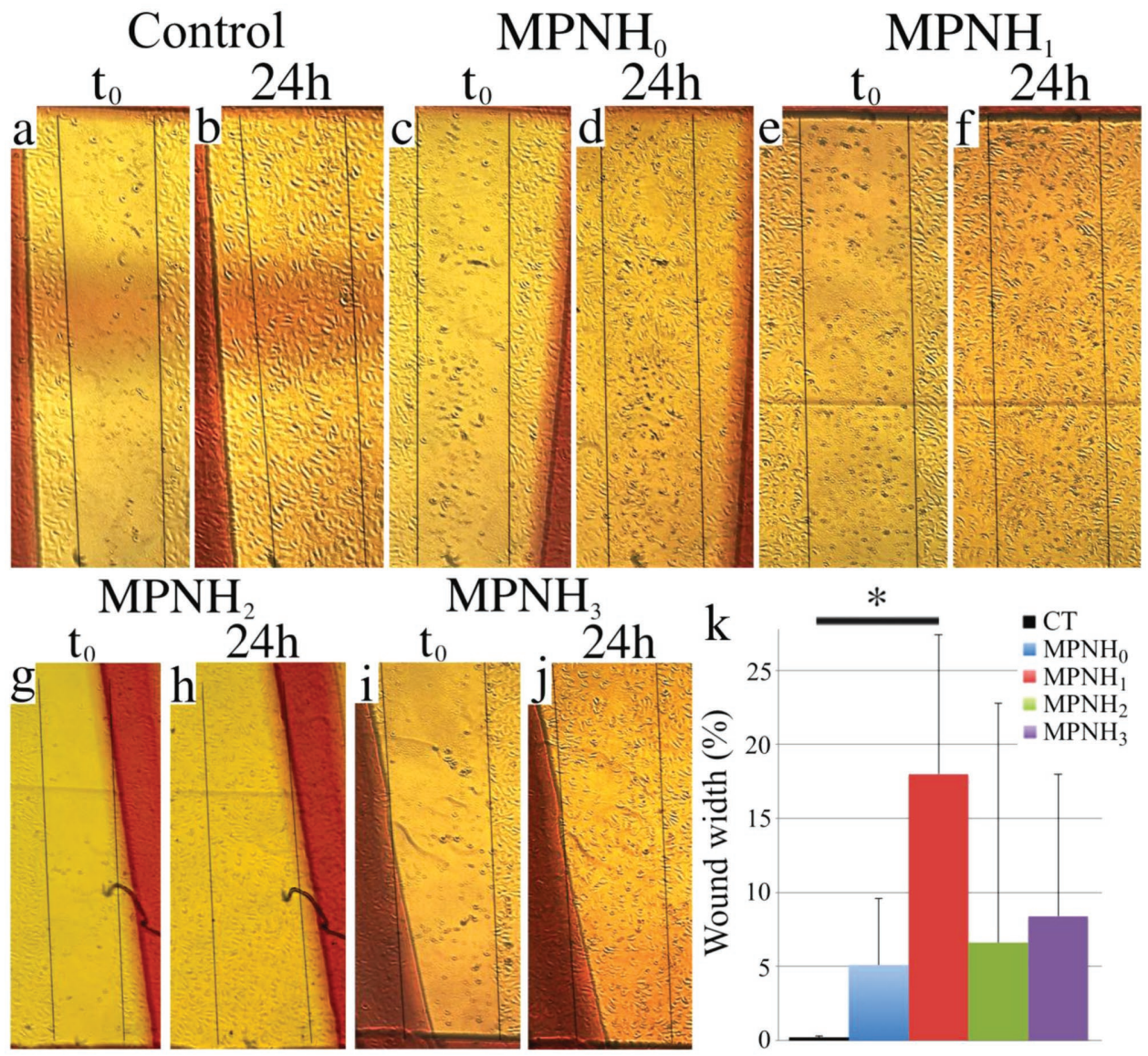

Figure 4. Assessment of the invasion ability of labeled ECFC. a-j) Images of wounds were taken $24 \mathrm{~h}$ after their realization, when control wounds had disappeared. k) Evaluation of invasion latency between control and labeled ECFC. Statistical analyses were realized using an Anova test followed by a Bonferroni comparison. Bar graphs show mean bar graph, which shows mean $\pm \mathrm{SD}$, * indicates $p<0.05$.

almost all closed after $24 \mathrm{~h}$. Compared to the untreated control, only cells treated with $\mathrm{MPNH}_{1}-\mathrm{COOH}$ showed significant decrease in the cell ability to close up the gap (Figure 4f,k). However, according to magnetophoresis results, $\mathrm{MPNH}_{1}{ }^{-} \mathrm{COOH}$ are the most internalized nanoparticles by ECFC among USPIOs containing MPNH. It is then conceivable that the greater internalization of $\mathrm{MPNH}_{1}-\mathrm{COOH}$ is responsible for the longer gap closing delay. It is worthwhile to precise that these results were obtained when cells were cultured in EGM-2 culture medium with $2 \%(\mathrm{v} / \mathrm{v})$ of fetal calf serum. This is necessary to avoid a bias due to cell proliferation: a control with $10 \%$ (v/v) of fetal calf serum showed no difference in the wound healing between control and labeled ECFC (data not shown).

As previously mentioned, ECFC have been shown to possess all the characteristics of endothelial progenitors to promote vascular repair and angiogenesis in vivo. ${ }^{[31,32]}$ Evaluating their ability to form vascular structures is one of the most specific ways to assess their ability to stimulate angiogenesis. This was tested in vitro by plating cells on constituents mimicking the extracellular matrix called Matrigel. Matrigel stimulates the organization of endothelial cells in networks evoking microvasculature. ECFC were labeled with MPNHs-COOH before seeding on Matrigel for $16 \mathrm{~h}$. Under these experimental conditions, labeled and control ECFC formed extensive tubular network and the labeling process did not affect their properties (Figure 5; Figure S3, Supporting Information). Typical characterizations of tubular structures include the total number of tubes and their mean lengths (Figure $5 \mathrm{f}$,g, respectively), but it is also possible to evaluate the mean covered area, the number of loops, the total length of the network, the loops mean areas and perimeters, as well as the total branching points (Figure S3a-f, respectively). As can be seen on the Figure 5 and Figure S3 (Supporting Information), there is no significant difference between the networks formed by labeled and non-labeled ECFC, regardless of the property under consideration. Similar results have already been reported in the literature using magnetic nanoparticles. ${ }^{[36]}$ Altogether, these results confirm the MPNHs innocuousness regarding ECFC proangiogenesis properties.

\subsection{Real-Time Dynamic Tracking and Magnetic Manipulation of Transplanted Cells In Vivo}

As a proof of concept, we carried out in vivo experiment to determine whether it was possible to follow the distribution of MPNH-labeled ECFC in real time by luminescence imaging and simultaneously to control their localization by magnetic fields. ECFC were labeled with $\mathrm{MPNH}_{0^{-}} \mathrm{COOH}$ or $\mathrm{MPNH}_{2-}$ 

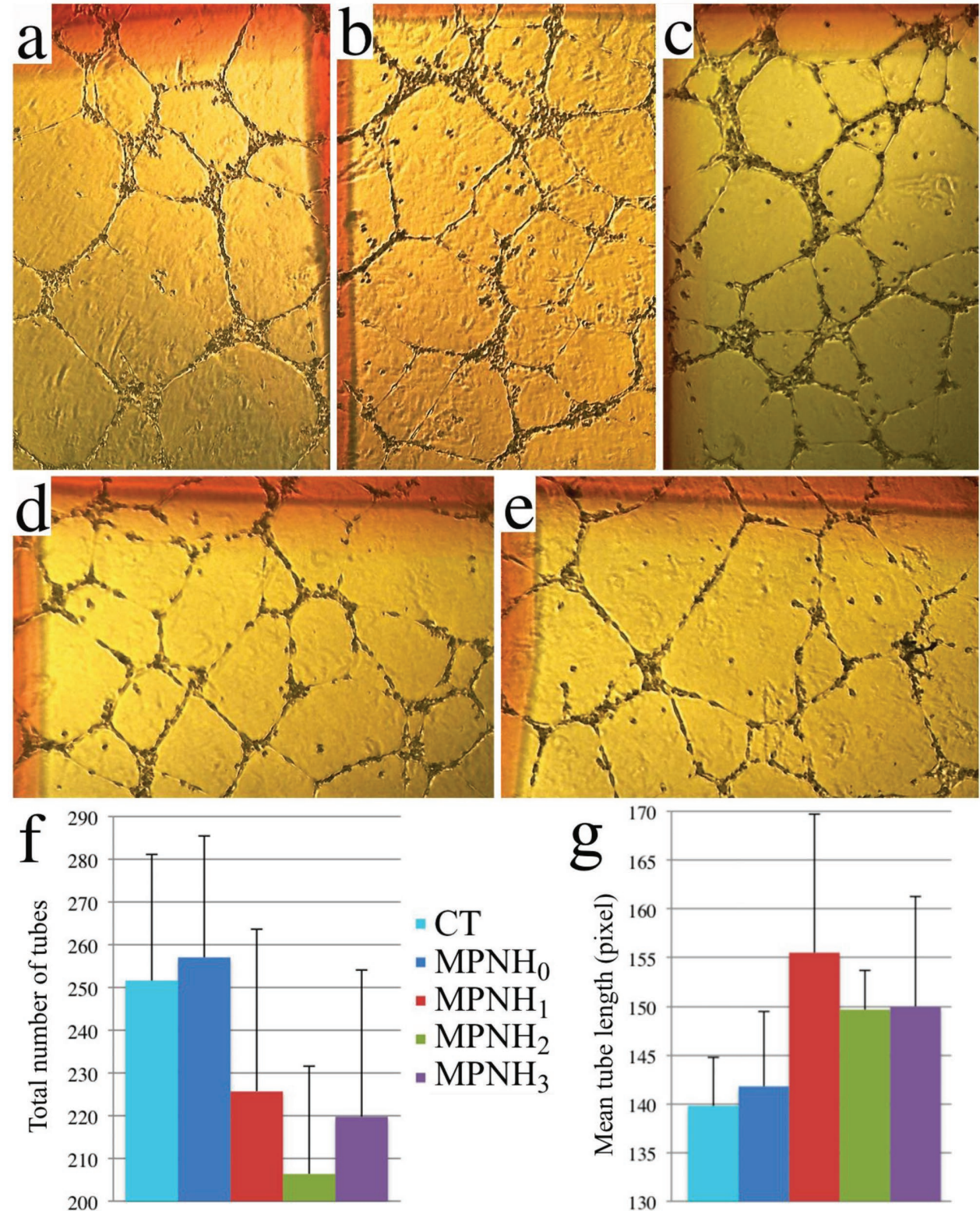

Figure 5. Vasculogenesis in vitro with labeled cells on Matrigel. a) Control and $\mathrm{MPNH}_{0,1,2,3-\mathrm{COOH}}$ (respectively, (b), (c), (d), and (e)) labeled ECFC were incubated at $37^{\circ} \mathrm{C}$ in EGM-2 during $16 \mathrm{~h}$ to form vascular tubes. Properties of the vascular network such as $\mathrm{f}$ ) the total number of tubes or g) the mean tube length were assessed with an online software (Wimasis). Bar graphs represent mean \pm SD.

$\mathrm{COOH}$ under the same conditions to those previously used. $5.10^{5}$ labeled ECFC were preilluminated by an orange LED for $5 \mathrm{~min}$ and were then injected in the peritoneal cavity of BALB/C mice. A luminescence image was acquired before and after applying a magnet to the right side of each mouse. The ECFC labeled with $\mathrm{MPNH}_{0}$ - $\mathrm{COOH}$ represent the control group since $\mathrm{MPNH}_{0}$ do not contain USPIOs and therefore do not react to the presence of a magnetic field gradient. To evaluate the influence of the presence of an external magnet on the distribution of ECFC, we monitored the persistent luminescence intensity for twelve minutes throughout five regions of interest along the abdominal cavity (red rectangles, Figure 6a). When looking at the signal of ECFC labeled with $\mathrm{MPNH}_{0}-\mathrm{COOH}$, it can be seen that the luminescence in the mice does not evolve (Figure 6b) and that the luminescence profile traced as indicated above is stable after applying the magnet against the right flank of the mouse (Figure 6d). On the contrary, when looking at the signal of $\mathrm{MPNH}_{2}-\mathrm{COOH}$ labeled ECFC, we observe a significant preferential accumulation with time of the luminescence situated in the right part of the abdomen toward the right flank of the mouse, where the magnet is placed (Figure 6c). Moreover, the luminescence coming from the left half side of the mice did not change over time, unlike that of the right side. The persistent luminescence signal increases significantly in the closest area to the magnet (Figure 6e). This graph confirms results from the luminescence images: the signal does not evolve at a 

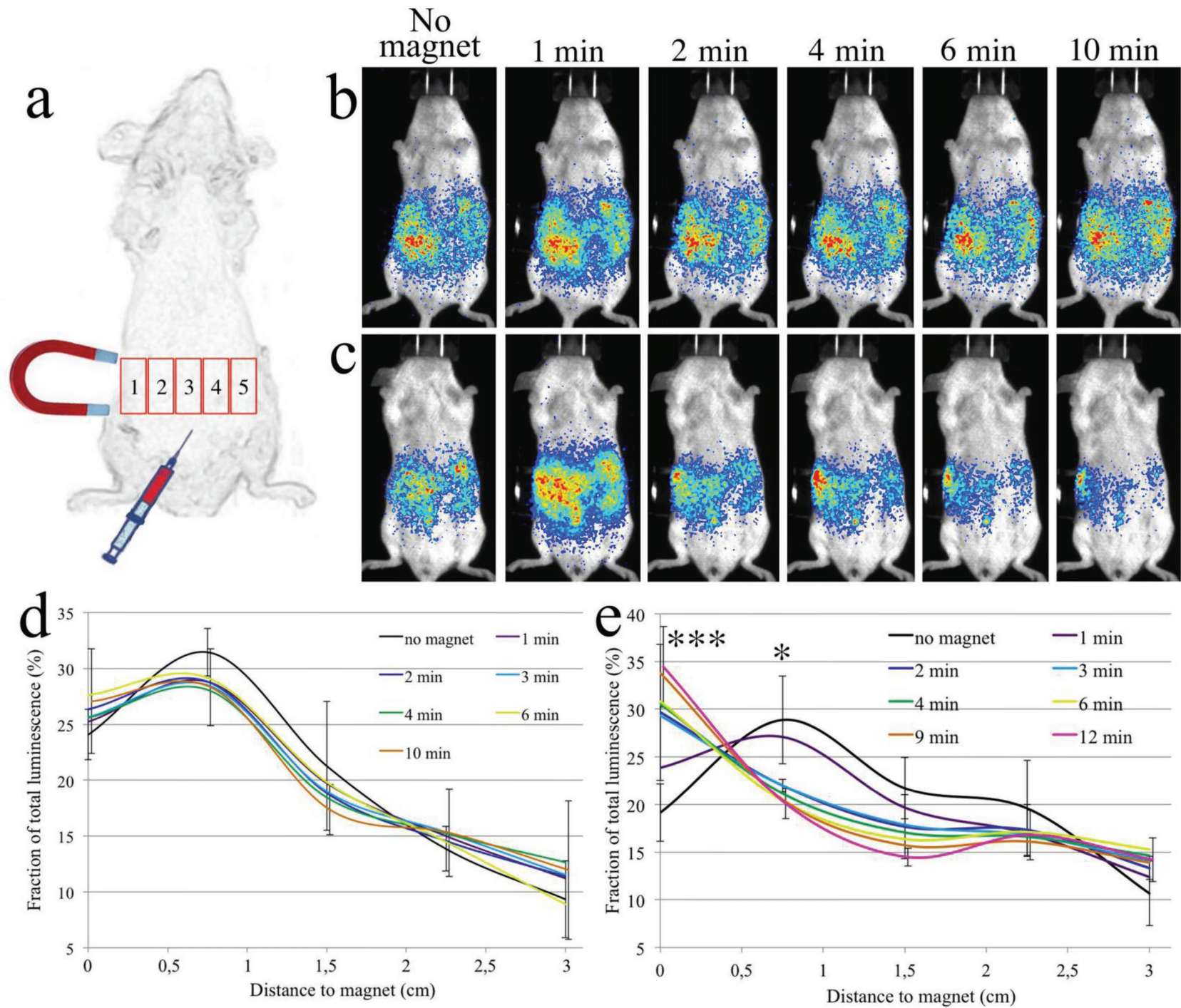

Figure 6. In vivo magnetic vectorization of labeled ECFC and real-time optical imaging of their biodistribution. a) Representation of the in vivo experiment and segmentation of mice abdomen to follow the evolution of the luminescence distribution. Characteristic evolution of persistent luminescence distribution in a mouse after injection of $\mathrm{MPNH}_{0}-\mathrm{COOH}$ labeled ECFC (b, control experiment) or $\mathrm{c}$ ) $\mathrm{MPNH}_{2}-\mathrm{COOH}$ labeled ECFC and corresponding graphs (respectively, (d) and (e)). Statistical analyses were realized between the luminescence intensities before and 12 min after magnet apposition using an Anova test followed by a Bonferroni comparison. * and ${ }^{2} \mathrm{k}^{*}$ indicate $p<0.05$ and $p<0.001$.

distance greater than $2 \mathrm{~cm}$ from the magnet. This makes it possible to determine an effective distance of action of the magnet on the $\mathrm{MPNH}_{2}$-COOH labeled ECFC. Furthermore, the most important evolution of the luminescence takes place during the 3 or 4 first minutes of the experiment, suggesting that once cell sedimentation or tissue adhesion happens, no more cell movement can occur in our experimental conditions.

These first experiments of magnetic cellular vectorization using MPNHs in vivo show the possibility to magnetically attract MPNH-loaded cells injected into the peritoneal cavity and to optically localize them in real time by luminescence measurements. This study proved, for the first time, the feasibility of using nanoparticles as a tool to magnetically vectorize and concomitantly track cell migration in vivo in real time, without unnecessary sacrifice of the animal. The noninvasive nature of this technique opens access to information regarding cell magnetic vectorization dynamics in living animals. This proof of concept was made possible in our situation because it was realized on mice. As near-infrared luminescence does not have an important penetration depth, its actual potential would be limited to preclinical studies on small animals, peroperative imaging, and surface applications (dermatology, gastrointestinal endoscopy). Another promising enhancement of this technique could be achieved using PLNP emitting in the second near-infrared window (between 1.0 and $1.4 \mu \mathrm{m}$ ), as penetration depth is higher for this wavelength range.

\section{Conclusion}

Nanoparticles with persistent luminescence and magnetic properties were integrated into nanohybrids in order to label cells of 
therapeutic interest. In this study, we showed that with such MPNHs, it is possible to define nontoxic labeling conditions, which allow cells tracking in real time using persistent luminescence. Moreover, this led to signals devoid of autofluorescence and allowed following the injected cells in vivo dynamic and attraction with a magnet. Our findings provide a proof of concept demonstrating that it is possible to realize real-time optical monitoring of magnetically targeted ECFC in vitro and in vivo with a good sensitivity using persistent luminescence. Thus, we postulate that, by applying an appropriate magnetic field gradient, the approach developed in this study could be useful to assess cell targeting to specific locations inside the body for cell-based therapies. This study also suggests the possibility to realize cell retention in the peritoneal cavity using our nanoparticles, which may be interesting for applications such as cancer cell therapies ${ }^{[45]}$ if similar results are further obtained with different kind of therapeutic cells.

\section{Experimental Section}

Chemicals and Biologics: Zinc nitrate hexahydrate (>99\%), diglycolic anhydride (>90\%), and dimethylhydroxylamine solution (40\%) were obtained from Fluka. Gallium oxide (99.999\%), chromium (III) nitrate nonahydrate $(99.99 \%)$, and sodium $n$-dodecyl sulfate $(99 \%)$ were purchased from Alfa Aesar. Dimethylformamide (>99.99\%) was purchased from SDS. CTAB $(>98 \%)$, tetraethyl orthosilicate (TEOS, $>98 \%$ ), iron (II) chloride tetrahydrate, caffeic acid, and $\mathrm{HCl}$ were purchased from Sigma-Aldrich. Water was purified with a Millipore system (resistivity $18.2 \mathrm{M} \Omega \mathrm{cm}$ ). HBSS and D-PBS were purchased from Dubco.

ECFC Isolation, Culture, and Labeling: Umbilical cord blood collected from consenting mothers was diluted in an equal volume of HBSS, and mononuclear cells were isolated by density-gradient centrifugation using $1.077 \mathrm{~g} \mathrm{~mL}^{-1}$ Histopaque solution (Sigma Chemicals, Saint Quentin Fallavier, France) as described by Bompais et al. ${ }^{[46]}$ CD34+ cells were selected with immunomagnetic beads and the MACS technique (Miltenyi Biotec, Paris, France). They were plated on $0.2 \%$ gelatin-coated 24-well plastic culture dishes at a density of 5.105 cells per well in endothelial growth medium (EGM-2, Lonza, Walkersville, $M D, U S A)$. After $4 \mathrm{~d}$, nonadherent cells were removed by thorough washing with culture medium. After $10 \mathrm{~d}$ of culture, ECFC colonies became visible microscopically. Cells were then detached with trypsinEDTA (Eurobio, Les Ulis, France) and expanded in EGM-@ on $0.2 \%$ gelatin coated plates and grown at $37{ }^{\circ} \mathrm{C}$ in a humidified $5 \% \mathrm{CO}_{2}$ atmosphere for further use. ECFC were used 25 to $45 \mathrm{~d}$ after cord blood processing.

Cell labeling was performed by adding a suspension of MPNHs in EGM-2 culture medium to adherent cells. Cells were incubated at $37{ }^{\circ} \mathrm{C}$ for different incubation times (6 or $24 \mathrm{~h}$ ) with various MPNH concentrations. Incubation was followed by two washes with MPNH-free D-PBS.

Synthesis and Functionalization of the Four Nanohybrids: Persistent luminescence nanoparticles $\left(\mathrm{ZnGa}_{2} \mathrm{O}_{4}: \mathrm{Cr}^{3+}\right)$, maghemite ultrasmall iron oxide nanoparticles $\left(\gamma-\mathrm{Fe}_{2} \mathrm{O}_{3}\right)$, and the four types of mesoporous nanohybrides were synthesized as previously described. [31]

The surface functionalization of MPNHs was realized as follow: MPNH ${ }_{0,1,2,3}-\mathrm{NH}_{2}$ nanoparticles were obtained by adding APTES $(40 \mu \mathrm{L})$ to a suspension of $\mathrm{MPNH}_{0,1,2,3} \mathrm{OH}(10 \mathrm{mg})$ in DMF $(4 \mathrm{~mL})$. The reaction mixture was sonicated for the first 2 min using a Branson Ultrasonic Cleaner 1210 and kept under vigorous stirring for $5 \mathrm{~h}$ at room temperature (RT). Particles were washed from the unreacted APTES by three centrifugation/redispersion steps in DMF. $\mathrm{MPNH}_{0,1,2,3}-\mathrm{COOH}$ were obtained by having DGA $(2.7 \mathrm{mg})$ reacted with $\mathrm{MPNH}_{0,1,2,3}-\mathrm{NH}_{2}$ particles $(10 \mathrm{mg})$ in DMF $(4 \mathrm{~mL})$ under vigorous stirring overnight at RT. After washing, $\mathrm{MPNH}_{0,1,2,3}-\mathrm{COOH}$ were dispersed in sterile glucose (5\%).

Alamar Blue Assay: Before realizing this assay, it is necessary to determine the linearity range of this test. Growing amounts of cells (nine conditions from $4.10^{3}$ to $2.10^{4}$ cells per well) were seeded in 96-well flat bottom plates (Falcon, Strasbourg, France) and incubated subsequently in complete culture medium, without Alamar Blue reagent for $24 \mathrm{~h}$ and with Alamar Blue for $5 \mathrm{~h}$. Fluorescence measurements were then realized every hour $\left(\lambda_{\mathrm{exc}}=530 \mathrm{~nm} / \lambda_{\mathrm{em}}=590 \mathrm{~nm}\right)$ with a Tecan Infinite Pro 2000 (Tecan Trading AG, Switzerland). This experiment allowed us to determine efficient conditions for the following cytotoxicity assays.

ECFC were seeded at a density of 104 cells per well in 96-well flatbottom plates and incubated in complete culture medium (EGM-2) for $24 \mathrm{~h}$. Then, medium was replaced by EGM-2 containing increasing concentrations of MPNH- $\mathrm{NH}_{2}$ or MPNH-COOH. After 6 or $24 \mathrm{~h}$, medium was removed and EGM-2 with Alamar Blue reagent $(10 \%, v / v)$ was added for $4 \mathrm{~h}$ at $37^{\circ} \mathrm{C}$. Cell viability is calculated from the measured fluorescence of metabolized Alamar Blue using a Tecan Infinite Pro 2000.

Cell Proliferation Assay: ECFC were seeded at a density of 103 cells per well in 96-well flat-bottom plates and incubated in complete culture medium overnight. Cells were then exposed $6 \mathrm{~h}$ to EGM-2 (control), MPNH-NH ${ }_{2}$ or MPNH-COOH suspensions in EGM-2 at the concentration of $0.25 \mathrm{mg} \mathrm{mL}^{-1}$. Mediums were then removed and three control wells, as well as three MPNH-treated wells, were treated as follow: the supernatants were removed, wells were gently washed using $300 \mu \mathrm{L}$ of DPBS, cells were treated with $20 \mu \mathrm{L}$ of trypsin-EDTA for $5 \mathrm{~min}$ at $37{ }^{\circ} \mathrm{C}$ before adding $40 \mu \mathrm{L}$ of $10 \%$ trypan blue (v/v) EGM-2, cells were transferred in an Eppendorf tube and another $20 \mu \mathrm{L}$ of EGM-2 was used to rinse the wells. Cells were then counted on a Malassez cell. This action was repeated over time.

Magnetophoresis: Cellular uptake was quantified by means of magnetophoresis, ${ }^{[47]}$ which consists of measuring the velocity of labeled cells in a magnetic field gradient of know cartography (magnetic field gradient gradB $=18.5 \mathrm{mT} \mathrm{mm}^{-1}$ ). The iron mass per cell is calculated from the balance of viscous force $(6 \pi \eta \mathrm{R} v, \eta$ being the water viscosity, $R$ the cell radius, $v$ the cell velocity) and the magnetic force $(M * \operatorname{gradB}, M$ being the cell magnetic moment). Measuring, from video analysis, the velocity $v$ and the radius $R$ of cells migrating toward the magnet, their magnetic moment or, equivalently, their iron mass $\mathrm{mFe}$ were obtained. In addition to the mean cellular magnetic load, this assay allows determining the iron mass distribution in the cell population $(n>87$ cells for each incubation condition).

Optical Characterization of Cells: Labeled cells were fixed in Eppendorf tubes containing a low gelling point agarose (BMA Products, USA) solution $3 \%(\mathrm{w} / \mathrm{v})$ at $38{ }^{\circ} \mathrm{C}$, and a concentration of 1.5.106 ECFC $\mathrm{mL}^{-1}$. Eppendorfs were then illuminated for $5 \mathrm{~min}$ before signal acquisition. Signal acquisition was carried out using a photon-counting system based on a cooled GaAs intensified charge-coupled device camera (Optima, Biospace, Paris, France).

Magnetic Characterization of Cells: The agarose gels were also used to perform MRI measurements. MRI was performed with a dedicated small-animal 4.7 Tesla MR system (Biospec 47/40 USR Bruker), using a quadrature transmit/receive body coil with a $35 \mathrm{~mm}$ inner diameter. A $5 \mathrm{~mm}$ water reference tube was also inserted. The T2 sequence was used with following parameters: TR $=12 \mathrm{~s}, 100 \mathrm{TE}$ were done from $9 \mathrm{~ms}$ with 9 ms between each, $149 \times 85$ matrix, 3 slices of $1 \mathrm{~mm}$ thickness, resolution $235 \times 235 \mu \mathrm{m}$, and FOV $=3.5 \times 2 \mathrm{~cm}$. The T1 sequence was used with following parameters: TE $=11 \mathrm{~s}, \mathrm{TR}=10 \mathrm{~s} / 7$ $\mathrm{s} / 4,5 \mathrm{~s} / 3 \mathrm{~s} / 1,5 \mathrm{~s} / 800 \mathrm{~ms} / 400 \mathrm{~ms} / 200 \mathrm{~ms} / 150 \mathrm{~ms} / 100 \mathrm{~ms} / 90 \mathrm{~ms}, 149$ $\times 85$ matrix, 3 slices of $1 \mathrm{~mm}$ thickness, resolution $235 \times 235 \mu \mathrm{m}$ and $\mathrm{FOV}=3.5 \times 2 \mathrm{~cm}$.

Scratch Test: Cell migration assays were performed by plating 3.105 ECFC on 6-well plates until confluence was reached. Then, the cells were treated with $73.5 \mu \mathrm{g} \mathrm{cm}^{-2}\left(0.25 \mathrm{mg} \mathrm{mL}^{-1}\right)$ of each MPNH-COOH for $6 \mathrm{~h}$. Wells were rinsed with PBS and three wounds were realized in each well using a P200 pipette tip. PBS supernatants were discarded and EGM-2 with 2 or $10 \%$ of serum was added. Wounds widths were measured $24 \mathrm{~h}$ after they were realized. The cells were imaged using a Nikon Diaphot 
inverted contrast microscope. The width of the wounds was quantified using Image). Six width measures were performed on three wounds for each condition.

In Vitro Tube Formation Assay: These experiments were carried out with cells labeled under the same conditions as for the previous experiments (MPNH-COOH, $6 \mathrm{~h}, 73.5 \mu \mathrm{g} \mathrm{cm}-2 / 0.25 \mathrm{mg} \mathrm{mL}^{-1}$ ). At the same time, 48-well plates were coated with $150 \mu \mathrm{L}$ of growth factor reduced Matrigel. Polymerization of Matrigel was realized at $37{ }^{\circ} \mathrm{C}$ for 1 h. $4.10^{4}$ control and labeled ECFC were loaded on Matrigel and incubated in EGM-2 for $16 \mathrm{~h}$ to allow cellular network structures to fully develop. Cell structures were imaged using a Nikon Diaphot inverted contrast microscope, and networks were characterized with the online software Wimasis Image Analysis, using the Wimtube protocol (www. wimasis.com/en/products/13/WimTube).

In Vivo Cell Imaging and Tracking: Animal studies were conducted in agreement with the French guidelines for animal care in compliance with procedures approved by the Paris Descartes ethics committee for animal research (ref. CEEA34.JS.142.12). Five weeks old female BALB/C mice (Janvier, Le Genest St. Isle, France) were anesthetized by oral inhalation of isoflurane. A quantity of $5.10^{5}$ ECFC was labeled with either $\mathrm{MPNH}_{0}-\mathrm{COOH}$ (control) or $\mathrm{MPNH}_{2}-\mathrm{COOH}$ under previously determined conditions $\left(6 \mathrm{~h}, 73.5 \mu \mathrm{g} \mathrm{cm}{ }^{-2} / 0.25 \mathrm{mg} \mathrm{mL}^{-1}\right)$. These ECFC were dispersed in $100 \mu \mathrm{L}$ of a $5 \%$ sterile D-PBS solution at a concentration of $5.10^{6} \mathrm{ECFC} \mathrm{mL}$. The suspension of labeled ECFC was first excited ex vivo for 5 min under an orange LED before injection in the peritoneal cavity of mice. Animals were then placed on their back under the photon-counting device, and the signal acquisitions were performed. A luminescence image was realized for ten seconds before applying a magnet against the right side of the mouse. Luminescence was then followed for ten minutes, until its distribution stops evolving. Four ring neodymium magnets (outer diameter $19.1 \mathrm{~mm}$, inner diameter $9.5 \mathrm{~mm}$, height $6.4 \mathrm{~mm}$, strength $75.5 \mathrm{~N}$, Supermagnete, Gottmadingen, Germany) were joined to be applied on the side of the mouse.

\section{Supporting Information}

Supporting Information is available from the Wiley Online Library or from the author.

\section{Acknowledgements}

The authors sincerely thank Anna Lokajczyk and Nour Bacha for their advices and help concerning ECFC cultures and experiments (from the laboratory "Therapeutiques innovantes en hémostase," Inserm U S1140), Johanne Seguin (from the UTCBS, CNRS UMR8258), René Lai-Kuen and Bruno Saubaméa (from the technological Platform of IFR71/IMTCE-Cellular \& Molecular Imaging), Dan Elgrabli (from the MSC, CNRS UMR7057), as well as Florence Delestre and Maurice Teston for their unwavering support. This work was supported by a grant from the Pres Sorbonne Paris-Cité (ODICEO project).

\section{Conflict of Interest}

The authors declare no conflict of interest.

\section{Keywords}

cell labeling, hybrids, imaging, magnetic vectorization, nanoparticles

Received: January 3, 2018

Revised: January 26, 2018 Published online:
[1] A. Trounson, C. McDonald, Cell Stem Cell 2015, 17, 11.

[2] N. J. Leeper, A. L. Hunter, J. P. Cooke, Circulation 2010, 122, 517.

[3] R. J. Morris, Y. Liu, L. Marles, Z. Yang, C. Trempus, S. Li, J. S. Lin, J. A. Sawicki, G. Cotsarelis, Nat. Biotechnol. 2004, 22, 411.

[4] W.-B. Shen, C. Plachez, O. Tsymbalyuk, N. Tsymbalyuk, S. Xu, A. Smith, S. Michel, D. Yarnell, R. Mullins, R. Gulapalli, A. Puche, J. M. Simard, P. S. Fishman, P. Yarowsky, Cell Transplant. 2016, 25, 1085

[5] M. Ishii, Y. Numaguchi, K. Okumura, R. Kubota, X. Ma, R. Murakami, K. Naruse, T. Murohara, Atherosclerosis 2009, 206, 109.

[6] F. Zemani, J.-S. Sylvestre, F. Fauvel-Lafeve, A. Bruel, J. Vilar, I. Bieche, I. Laurendeau, I. Galy-Fauroux, A.-M. Fischer, C. BoissonVidal, Arterioscler., Thromb., Vasc. Biol. 2008, 28, 644.

[7] I. M. Barbash, P. Chouraqui, J. Baron, M. S. Feinberg, S. Etzion, A. Tessone, L. Miller, E. Guetta, D. Zipori, L. H. Kedes, R. A. Kloner, J. Leor, Circulation 2003, 108, 863.

[8] D. J. Brenner, E. J. Hall, N. Engl. J. Med. 2007, 357, 2277.

[9] M. Modo, J. Kolosnjaj-Tabi, F. Nicholls, W. Ling, C. Wilhelm, O. Debarge, F. Gazeau, O. Clement, Contrast Media Mol. Imaging 2013, 8, 439 .

[10] C. Yoshida, A. B. Tsuji, H. Sudo, A. Sugyo, C. Sogawa, N. Inubushi, T. Uehara, T. Fukumura, M. Koizumi, Y. Arano, T. Saga, Nucl. Med. Biol. 2011, 38, 331.

[11] J. L. Ortiz, A. Ortiz, J. Milara, M. Armengot, C. Sanz, D. Compan, E. Morcillo, J. Cortijo, PLoS One 2016, 11, e0164399.

[12] J. Li, W. Y. Lee, T. Wu, J. Xu, K. Zhang, G. Li, J. Xia, L. Bian, Adv. Helthcare Mater. 2016, 77, 14.

[13] H. Yukawa, S. Mizufune, C. Mamori, Y. Kagami, K. Oishi, N. Kaji, Y. Okamoto, M. Takeshi, H. Noguchi, Y. Baba, M. Hamaguchi, N. Hamajima, S. Hayashi, Cell Transplant. 2009, 18, 591.

[14] H. Yukawa, M. Watanabe, N. Kaji, Y. Baba, Cell Med. 2015, 7, 75.

[15] Q. le Masne de Chermont, C. Chanéac, J. Seguin, F. Pellé, S. Maîtrejean, J.-P. Jolivet, D. Gourier, M. Bessodes, D. Scherman, Proc. Natl. Acad. Sci. USA 2007, 104, 9266.

[16] T. Maldiney, A. Lecointre, B. Viana, A. Bessiere, M. Bessodes, D. Gourier, C. Richard, D. Scherman, J. Am. Chem. Soc. 2011, 133, 11810.

[17] T. Maldiney, B. Viana, A. Bessiere, D. Gourier, M. Bessodes, D. Scherman, C. Richard, Opt. Mater. 2013, 35, 1852.

[18] T. Maldiney, A. Bessière, J. Seguin, E. Teston, S. K. Sharma, B. Viana, A. J. J. Bos, P. Dorenbos, M. Bessodes, D. Gourier, D. Scherman, C. Richard, Nat. Mater. 2014, 13, 418.

[19] T. Lécuyer, E. Teston, G. Ramirez-Garcia, T. Maldiney, B. Viana, J. Seguin, N. Mignet, D. Scherman, C. Richard, Theranostics 2016, 6, 2488.

[20] E. Teston, S. Richard, T. Maldiney, N. Lièvre, G. Yangshu Wang, L. Motte, C. Richard, Y. Lalatonne, Chem. - Eur. J. 2015, 21, 7350.

[21] S.-Q. Wu, C.-W. Chi, C.-X. Yang, X.-P. Yan, Anal. Chem. 2016, 88, 4114.

[22] S.-Q. Wu, C.-X. Yang, X.-P. Yan. Adv. Funct. Mater. 2017, 27, 1604992.

[23] S. K. Sanganalmath, R. Bolli, Circ. Res. 2013, 113, 810.

[24] G. Vunjak-Novakovic, K. O. Lui, N. Tandon, K. R. Chien, Annu. Rev. Biomed. Eng. 2011, 13, 245.

[25] B. Polyak, I. Fishbein, M. Chorny, I. Alferiev, D. Williams, B. Yellen, G. Friedman, R. J. Levy, Proc. Natl. Acad. Sci. USA 2008, 105, 698.

[26] L. Cheng, C. Wang, X. Ma, Q. Wang, Y. Cheng, H. Wang, Y. Li, Z. Liu, Adv. Funct. Mater. 2013, 23, 272.

[27] A. Chaudeurge, C. Wilhelm, A. Chen-Tournoux, F. Farahmand, V. Bellamy, G. Autret, C. Ménager, A. Hagège, J. Larghéro, F. Gazeau, O. Clément, P. Menasché, Cell Transplant. 2012, 21, 679.

[28] J. Riegler, A. Liew, S. O. Hynes, D. Ortega, T. O'Brien, R. M. Day, T. Richards, F. Sharif, Q. A. Pankhurst, M. F. Lythgoe, Biomaterials 2013, 34, 1987. 
[29] B. Polyak, M. Medved, N. Lazareva, L. Steele, T. Patel, A. Rai, M. Y. Rotenberg, K. Wasko, A. R. Kohut, R. Sensenig, G. Friedman, ACS Nano 2016, 10, 9559.

[30] E. Teston, Y. Lalatonne, D. Elgrabli, G. Autret, L. Motte, F. Gazeau, D. Scherman, O. Clément, C. Richard, T. Maldiney, Small 2015, 11, 2696.

[31] M. C. Yoder, L. E. Mead, D. Prater, T. R. Krier, K. N. Mroueh, F. Li, R. Krasich, C. J. Temm, J. T. Prchal, D. A. Ingram, Blood 2007, 109, 1801.

[32] C. Bouvard, B. Gafsou, B. Dizier, I. Galy-Fauroux, A. Lokajczyk, C. Boisson-Vidal, A.-M. Fischer, D. Helley, Arterioscler., Thromb., Vasc. Biol. 2010, 30, 1569.

[33] T. Maldiney, B. Ballet, M. Bessodes, D. Scherman, C. Richard, Nanoscale 2014, 6, 13970.

[34] A. M. Abdelmonem, B. Pelaz, K. Kantner, N. C. Bigall, P. del Pino, W. J. Parak, J. Inorg. Biochem. 2015, 153, 334.

[35] T.-H. Chung, S.-H. Wu, M. Yao, C.-H. Lu, Y.-S. Lin, Y. Hung, C.-Y. Mou, Y.-C. Chen, D.-M. Huang, Biomaterials 2007, 28, 2959.

[36] C. Wilhelm, L. Bal, P. Smirnov, I. Galy-Fauroux, O. Clément, F. Gazeau, J. Emerich, Biomaterials 2007, 28, 3797.
[37] Z. Orynbayeva, R. Sensenig, B. Polyak, Nanomedicine 2015, 10, 1555.

[38] D.-M. Huang, Y. Hung, B.-S. Ko, S.-C. Hsu, W.-H. Chen, C.-L. Chien, C.-P. Tsai, C.-T. Kuo, J.-C. Kang, C.-S. Yang, C.-Y. Mou, Y.-C. Chen, FASEB J. 2005, 19, 2014.

[39] J. Kolosnjaj-Tabi, C. Wilhelm, O. Clément, F. Gazeau, J. Nanobiotechnol. 2013, 11, S7.

[40] M. Levy, C. Wilhelm, M. Devaud, P. Levitz, F. Gazeau, Contrast Media Mol. Imaging 2012, 7, 373.

[41] F. Gazeau, C. Wilhelm, Future Med. Chem. 2010, 2, 397.

[42] J. Emmerich, Int. J. Lower Extremity Wounds 2005, 4, 234.

[43] H. Lawall, P. Bramlage, B. Amann, J. Vasc. Surg. 2011, 53, 445.

[44] C. C. Liang, A. Y. Park, J. L. Guan, Nat. Protoc. 2007, 2, 329.

[45] S. C. Katz, G. R. Point, M. Cunetta, M. Thorn, P. Guja, N. J. Espat, C. Boutros, N. Hanna, R. P. Junghans, Cancer Gene Ther. 2016, 23, 142.

[46] H. Bompais, J. Chagraoui, X. Canron, M. Crisan, X. H. Liu, A. Anjo, C. Tolla-Le Port, M. Leboeuf, P. Charbord, A. Bikfalvi, G. Uzan, Blood 2004, 103, 2577.

[47] C. Wilhelm, F. Gazeau, J. C. Bacri, Eur. Biophys. J. 2002, 31, 118. 